valve prolapse. Left ventricular systolic and diastolic function was similar in the two groups, but the internal dimension of the left ventricle at the end of diastole was slightly greater in those with mitral valve prolapse than in those without it. Some $30 \%$ of the first 100 people identified as having mitral valve prolapse had at least one relative with mitral valve prolapse, and the familial occurrence was greater in young women.

The Framingham study has shown that few patients with echocardiographic mitral valve prolapse show its clinical features, and that only about half of the people with systolic clicks have echocardiographic mitral valve prolapse. These findings contrast with the published clinical series, which have consisted almost wholly of patients ascertained on account either of symptoms or of complications, and most of these have had clicks and murmurs. Patients with abnormal clinical findings are much more likely to come to the attention of cardiologists than those without, and possibly also the presence of symptoms and signs may make the patients more at risk of serious disease.

The observation that echocardiographic mitral leaflet prolapse is most common in thin young women is in direct contrast with the usual clinical associations of a floppy valve. It strongly suggests that clinically silent echo prolapse in young women has nothing to do with the floppy valve or the complication of chordal lengthening or rupture needing mitral valve replacement, which are commonest in elderly men. ${ }^{16-18}$ Until we know more it seems prudent to regard patients with auscultatory and echocardiographic features of floppy mitral valve as possible candidates for complications and to protect them against endocarditis, but to regard "echo only" mitral valve prolapse as a variant of normal-a phenomenon as transient as youth and incompatible with increasing age and girth. Follow up of the population detected in the Framingham study is important, but we predict that they will do well.

Celia M Oakley

Consultant Cardiologist,

Royal Postgraduate Medical School,

London W12 0HS

\footnotetext{
I Barlow JB, Pocock WA, Marchand P, Denny M. The significance of late systolic murmurs. Am Heart f 1963;66:443-52.

Reid JVO. Mid-systolic click. African Medical fournal 1961;135:353-5

Pomerances A. Ballooning deformity (mucoid degeneration) of atrioventricular valves. Br Heart $\mathcal{J}$

1969;31:343-51.
Davies MJ, Moore BP, Braimbridge MV. The floppy mitral valve: study of incidence, pathology,
and complications in surgical necropsy, and forensic material. $B r$ Heart $\mathcal{f} 1978 ; 40: 468-81$ and complications in surgical, necropsy, and forensic material. Br Heart f 1978;40:468-81.
Olsen EGJ, Al-Rufaie HK. The floppy mitral valve: study on pathogenesis. Br Heart 1980;44:674-83.

Rippe J, Fishbein MC, Carabello B, et al. Primary myxomatous degeneration of cardiac valves: clinical, pathological, haemodynamic and echocardiographic profile. BrHeart $\mathcal{Y}$ 1980;44:621-9. Read RC, Thal AP, Wendy VE. Symptomatic valvular transformation the floppy valve syndrome): a possible forme fruste of the Marfan syndrome. Circulation 1965;32:897-910. Beton DC, Brear SG, Edwards JD, Leonard JC. Mitral valve prolapse: an assessment of clinical features, associated conditions and prognosis. $Q \mathcal{F}$ Med 1983;52:150-64.

Josephson ME, Horowitz LN, Kastor JA. Paroxysmal supraventricular tachycardia in patients with mitral valve prolapse. Circulation 1978;57:111-5.

Winkle RA, Lopez MG, Popp RI, Hancock EW. Life-threatening arrhythmias in the mitral valve prolapse syndrome. Am 7 Med 1976;60:961

DeMaria AN, Amsterdam EA, Vismara LA, Neumann A, Mason DT. Arrhythmias in the mitral

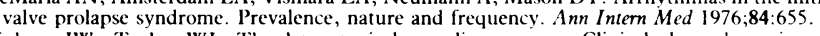

Linhart JW, Taylor WJ. The late atypical systolic murmur. Clinical, hemodynamic and

Woolegraphic observations. $A m f$ Cardiol $1966 ; 18: 164$.

syndrome, soldiers' heart, the effort 1976;53:749.

${ }^{14}$ Lachman AS, Bramwell-Jones DM, Lakier JB, Pocock WA, Barlow JB. Infective endocarditis in

the billowing mitral leaflet syndrome. Br Heart $\mathcal{F}$ 1975;37:326-30.
Clemens JD, Horwitz RI, Jaffe CC, Feinstein AR, Stanton BF. A controlled evaluation of the risk of bacterial endocarditis in persons with mitral valve prolapse. $N$ Engl f Med 1982; 307:776-81.

Guy FC, MiDonald RPR, Fraser DB, Smith ER. Mitral valve prolapse as a cause of hemodynamically important mitral regurgitation. Can J Surg 1980;23:166.

Waller BF, Morrow AG, Maron BJ, et al. Etiology of clinically isolated severe, chronic, pure mitral regurgitation: analysis of 97 patienis over 30 years of age having mitral valve replacement. Am Heart f 1982;104:276.

Davies MJ, Moore BO, Braimbridge MV. The floppy mitral valve. Study of incidence, pathology and complications in surgical, necropsy and forensic material. Br Heart $f$ 1978;40:468-81.

prolapse? Lancet 1977; iii:313-6.

Wrolson LA, Keeling PWN, Malcolm AD, Russell RWR, Webb-Peploe MM. Visual complica tions of mitral valve prolapse. Br Med $\mathcal{f}$ 1977; ii :86-8.

(he mitral click-murmur syndrome. N Engl f Med 1973;289:127.
}

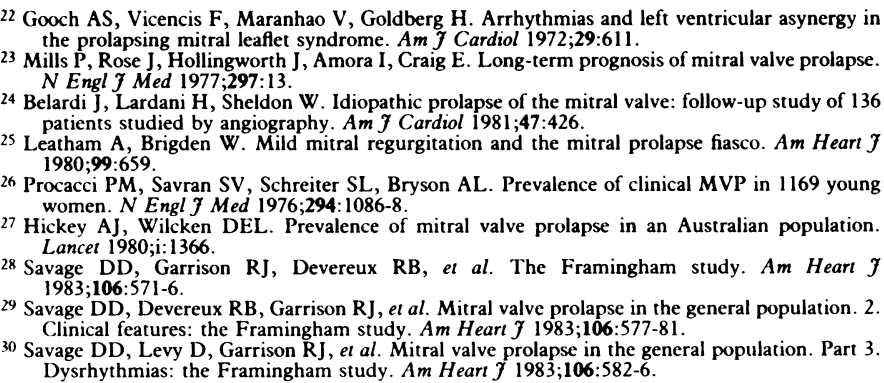

22 Gooch AS, Vicencis F, Maranhao V, Goldberg $H$. Arrhythmias and left ventricular asynergy in the prolapsing mitral leaflet syndrome. Am $\mathcal{J}$ Cardiol 1972;29:611

, Rose J, Hollingworth J, Amora I, Craig E. Long-term prognosis of mitral valve prolapse. N Engl f Med 1977;297:13.

Belardi J, Lardani $H$, Sheldon W. Idiopathic prolapse of the mitral valve: follow-up study of 136 patients studied by angiography. Am $\mathcal{C}$ Cardiol 1981;47:426.

1980;99:659.

women. N Engl f Med 1976;294:1086-8
wome Lancet Af, Wilcken

Salo 2. Clinical features: the Framingham study. Am Heart $\mathcal{J} 1983 ; 106: 577-81$. Savage DD, Levy D, Garrison RJ, et al. Mitral valve prolapse in the general population. Part 3.
Dysrhythmias: the Framingham study. Am Heart $\mathcal{O}$ 1983;106:582-6.

\section{Length of stay and health outcome}

As part of a general search for ways of making more efficient use of scarce hospital resources length of stay has long been a candidate for scrutiny. In 1974 the length of stay in hospital for repair of an inguinal hernia averaged 7.3 days in England and Wales. By 1980 the figure had fallen to $5 \cdot 8$ days with a range among regional health authorities of 4.2 to 6.6 days. ${ }^{12}$ In the United States, perhaps because most insurers now have to pay for each day in hospital, the lengths of stay for hernia repair have been lower still-5.8 days in 1974 and 5.0 in $1980 .^{34}$

Clearly average length of stay itself conceals considerable variation among patients and hospitals and regions, and, moreover, it is rarely entirely clear whether the patients to which the data refer are comparable. Indeed, the age standardised rate of repair of hernia in the United States is twice as high as in England and Wales, raising the question whether part of the remaining difference is attributable to the American patients being fitter when the surgery is performed."

In the United States cost containment is an overriding objective for government and health care planners, and accordingly length of stay statistics have been a central concern of bodies such as the Professional Standards Review Organisations. In part this is because in the search for savings length of stay is an easy target-unlike for instance use of diagnostic services which cannot be so readily questioned. Moreover, length of stay is easily and routinely measured and can be related to individual inpatients. For those concerned to compare, evaluate, and monitor, however, figures for length of stay may fall too easily out of routine health statistics publications. Their widespread use for administration and control may beg more questions than they can answer.

A recent case study from the Office of Technology Assessment of the United States Congress has provided insights into the depths of our collective ignorance. ${ }^{6}$ The starting point of Variations in Hospital Length of Stay: Their Relationship to Health Outcomes was the persistence of long hospital stays in the north east of the United States relative to short stays in the west. These differences remained after adjustment for the age, sex, and race of the two populations. The authors suggested that the differences might be due to a greater severity of hospital cases in the north east or to regional differences in clinical practice. Most important, they wanted to know what effects on health outcome these variations in length of stay might have.

The study concluded initially that systematic regional differences in length of stay were not determined by crude indices of case mix. In other words no evidence was found that the longer stays could be justificd by more serious cases. 
Oddly, the authors did not investigate the part played by supply in explaining some of the differences. Variations in the available beds per 1000 population might be a determinant of such differences, particularly as they have remained consistent over 15 years and among most diagnostic groups. ${ }^{7}$ Moreover, in the United States the relative variation of the number of doctors per 1000 population is quite large across regions, and that variation, too, might be partly responsible for the differences. ${ }^{8}$

Ten years ago Maxwell suggested that if France were to adopt the United States length of stay it would require only half as many hospital beds to still treat the same number of patients. ${ }^{9}$ The causes of variations in length of stay are clearly complicated and probably depend on aggregated hospital supply, national norms, local pressures, and individual discretion as well as the characteristics of patients. The Office of Technology Assessment review also looked carefully at publications on the crucial question of health outcome and its relation to length of stay. (The authors stated repeatedly that their goal was to determine standards for length of stay from such research, with which regional or hospital figures could be compared. This seems a naive and slightly misplaced hope, for there are too many imponderables for any standard to be useful as a yardstick.) They found 17 randomised comparisons of the effect of length of stay on health outcome which they rated as methodologically sound. These were restricted to the treatment of myocardial infarction, selected surgical operations, obstetrics, and psychiatry, and the reports were well reviewed. The conclusions were disappointing, however, for it proved impossible to compare with any useful certainty the relative efficacy of short stay against long stay for any of these treatments. Only extremely large effects could be excluded. Of the trials reported, none had more than a $75 \%$ chance of detecting a halving of either morbidity rates or mortality by changing length of stay (usually reducing it). On first principles one might generally expect a more modest effect than that.

Why, then, have questions about length of stay not been examined more seriously? Perhaps the answer lies in the nature of the underlying economic arguments. Hospital costs, per head, for a community depend on the product of admission rates with average cost per case. Clearly changing length of stay directly affects only the latter-and since a shortening saves time in hospital when costs are lowest this time saved might be taken up by admission of a new patient for whom the daily costs would be higher. More shorter admissions may well increase the overall costs. In the United States this effect has been forecast as one of the consequences of the new legislation providing for some reimbursement for hospital care according to diagnostic related groups. ${ }^{10} \mathrm{Re}-$ imbursement will no longer depend on hospital stay but exclusively on the 467 diagnostic related groups into which each patient is categorised.

Here in Britain we have the added complication of devolving care to the open ended facilities of the general practitioners, and community services. (Since 1977, according to Metcalfe, each general practitioner has had an extra 710 patient days added to his or her responsibility as a consequence of shorter hospital stays. $\left.{ }^{11}\right)$ Hence the case for shortening length of stay for care which is at all discretionary in order to reduce expenditure becomes obscured by the need to justify both the extra expenditure on patients who would not be otherwise admitted, at least at that time, and the net costs incurred outside the hospital.

Furthermore, the crucial question of whether shortening length of stay would increase the efficiency of provision of health care must remain open until we can devise (and obtain funding for) satisfactory research protocols to provide reliable estimates of the relative effectiveness of different lengths of stay on pertinent measures of outcome. At least for most common surgical procedures in the United States, however, variations in admission rates are a stronger determinant of costs per head than are lengths of stay. ${ }^{12}$ Moreover, admission rates are no more variable among hospital service areas in the United States than they are in Britain. ${ }^{13}$ The question of efficiency cannot be answered finally, therefore, until we know which admission policy yields greater benefits in terms of health outcome. If our aim is to increase the efficiency of the provision of health care it is this question that deserves the greatest amount of attention.

\section{KLIM MCPHERSON}

Lecturer in Medical Statistics,

Department of Community Medicine and

General Practice,

University of Oxford,

Oxford OX2 6HE

1 Office of Population Censuses and Surveys. Hospital in-patient enquiry. Main tables. 1980. London: HMSO, 1980. (Series MB4, No 15.)

${ }^{2}$ Office of Population Censuses and Surveys. Hospital in-patient enquiry. Main tables. 1974. London: HMSO, 1974. (Series MB4, No 2.)

${ }^{3}$ National Center for Health Statistics. Vital and health statistics, series 13. 1974:No 26. (DHEW publication No (HRA)76-1777.)

${ }^{4}$ National Center for Health Statistics. Vital and health statistics, series 13. 1980:No 64. (DHEW publication No (PHS)82-1725.)

5 McPherson K, Strong PM, Epstein A, Jones L. Regional variations in the use of common surgical procedures: within and between England and Wales, Canada and the United States of America. Soc Sci Med [A] 1981; $15: 273-88$.

- Office of Technology Assessment. Variations in hospital length of stay: their relationship to health outcomes. Washington: Office of Technology Assessment of the United States Congress, 1983. (Health Technology Case Study 24.)

7 Feldstein MS. Economic analysis for health service efficiency. Amsterdam: North-Holland Publishing Co, 1968.

${ }^{8}$ American College of Surgeons. American Surgical Association. Surgery in the United States. A summary report of the study on surgical services for the United States. Chicago: American College of Surgeons. American Surgical Association, 1976.

9 Maxwell R. Health care: the growing dilemma. London: Mckinsey and Co, 1974.

${ }^{10}$ Simborg DW, Creep DRG. A new hospital-acquired disease. $N$ Engl $\mathcal{F}$ Med $1981 ; 304: 1602-4$.

${ }^{11}$ Metcalfe D. Trends in the utilization of the National Health Service. $\mathcal{f} R$ Coll Gen Pract 1983;33:615-7.

12 Wennberg JE, Barnes BA, Zubkuff M. Professional uncertainty and the problem of supplier-induced demand. Soc Sci Med 1982;16:811-24.

${ }^{13}$ McPherson K, Wennberg JE, Hovind OB, Clifford P. Small-area variations in the use of common surgical procedures: an international comparison of New England, England, and Norway. $N$ Engl $f$ Med 1982; $307: 1310-4$.

\section{Systemic sclerosis: a collagen or microvascular disease?}

The concept of "collagen disease" was introduced by Klemperer and colleagues in 1942 to describe connective tissue disorders such as rheumatoid arthritis, systemic lupus erythematosus, and polyarteritis nodosa. ${ }^{1}$ Klemperer observed fibrinoid degeneration in collagen suggesting a basis for development of these disorders. Further study has shown that the structure and metabolism of collagen are largely unaltered in these diseases; the changes that occur in collagen are secondary to other biochemical and immunological events-yet, inappropriate as it may be, the name remains in use.

Systemic sclerosis has remained as the archetypal collagen 